Correspondence

H. Christensen

hech@life.ku.dk

\section{Classification of organisms previously reported as the SP and Stewart-Letscher groups, with descriptions of Necropsobacter gen. nov. and of Necropsobacter rosorum sp. nov. for organisms of the SP group}

\author{
H. Christensen, ${ }^{1}$ B. M. Korczak, ${ }^{2}$ A. M. Bojesen, ${ }^{1}$ P. Kuhnert, ${ }^{2}$ \\ W. Frederiksen ${ }^{1}$ and M. Bisgaard ${ }^{1}$
}
${ }^{1}$ Department of Veterinary Disease Biology, Faculty of Life Sciences, University of Copenhagen, 4 Stigboejlen, DK-1870 Frederiksberg C, Denmark
${ }^{2}$ Institute of Veterinary Bacteriology, Vetsuisse-Faculty, University of Bern, $\mathrm{CH}-3001$ Bern, Switzerland

To allow classification of bacteria previously reported as the SP group and the Stewart-Letscher group, 35 isolates from rodents (21), rabbits (eight), a dog and humans (five) were phenotypically and genotypically characterized. Comparison of partial rpo $B$ sequences showed that 34 of the isolates were closely related, demonstrating at least $97.4 \%$ similarity. $16 \mathrm{~S}$ rRNA gene sequence comparison of 20 selected isolates confirmed the monophyly of the SP group and revealed 98.5\%-100\% similarity between isolates. A BLAST search using the 16S rRNA gene sequences showed that the highest similarity outside the SP group was $95.5 \%$ to an unclassified rat isolate. The single strain, P625, representing the Stewart-Letscher group showed the highest 16S rRNA gene similarity (94.9-95.5\%) to members of the SP group. recN gene sequence analysis of 11 representative strains resulted in similarities of 97-100\% among the SP group strains, which showed $80 \%$ sequence similarity to the Stewart-Letscher group strain. Sequence similarity values based on the recN gene, indicative for whole genome similarity, showed the SP group being clearly separated from established genera, whereas the Stewart-Letscher group strain was associated with the SP group. A new genus, Necropsobacter gen. nov., with only one species, Necropsobacter rosorum sp. nov., is proposed to include all members of the SP group. The new genus can be separated from existing genera of the family Pasteurellaceae by at least three phenotypic characters. The most characteristic properties of the new genus are that haemolysis is not observed on bovine blood agar, positive reactions are observed in the porphyrin test, acid is produced from (+)-L-arabinose, (+)-D-xylose, dulcitol, (+)-D-galactose, (+)-D-mannose, maltose and melibiose, and negative reactions are observed for symbiotic growth, urease, ornithine decarboxylase and indole. Previous publications have documented that both ubiquinones and demethylmenaquinone were produced by the proposed type strain of the new genus, Michel $A / 76^{\top}$, and that the major polyamine of representative strains (type strain not included) of the genus is 1,3-diaminopropane, spermidine is present in moderate amounts and putrescine and spermine are detectable only in minor amounts. The major fatty acids of strain Michel $A / 76^{\top}$ are $C_{14: 0}, C_{16: 0}, C_{16: 1} \omega 7 c$ and summed feature $C_{14: 0} 3-O H /$ iso- $_{16: 1}$ I. This fatty acid profile is typical for members of the family Pasteurellaceae. The $\mathrm{G}+\mathrm{C}$ content of DNA of strain Michel $A / 76^{\top}$ was estimated to be $52.5 \mathrm{~mol} \%$ in a previous investigation. The type strain is $\mathrm{P} 709^{\top}$ (=Michel A/76 ${ }^{\top}=$ CCUG $28028^{\top}=$ CIP $110147^{\top}=\mathrm{CCM} 7802^{\top}$ ).

Abbreviations: MR, methyl red; SL, Stewart-Letscher.

The GenBank/EMBL/DDBJ accession numbers for the 16S rRNA gene sequences determined in this study are GU951545, GU966646-GU966656 and GU565606-GU565613. Those for the partial rpoB gene sequences are GU966657, GU966658 and GU565614-GU565621, and those for the recN gene sequences are GU565622-GU565632.

Two supplementary tables and two supplementary figures are available with the online version of this paper. 
At the time of writing, the family Pasteurellaceae includes 15 genera with validly published names, with Chelonobacter and Basfia most recently described (Christensen \& Bisgaard, 2008; Gregersen et al., 2009; Kuhnert et al., 2010). In this study, we report the features of a group of organisms mainly isolated from clinically affected rodents, and suggest that this group be classified in a new genus.

Organisms tentatively named the SP group were first reported by Frederiksen (1981), the name referring to an abbreviation for 'Sektionsprotocol' (sectio L. 'an act of cutting' protocol), the original notes made on a necropsy, an experiment or a case of disease. Isolates reported included five strains from guinea pigs, two human isolates from blood and faeces, respectively, and an isolate from guinea pig previously reported by Stewart \& Letscher (1976). An organism (Michel A/76 ${ }^{\mathrm{T}}$; Supplementary Table S1, available in IJSEM Online) sharing the phenotypic characters of the SP group, isolated from pneumonic lung tissue of a guinea pig after a spontaneous death, had previously been reported by Mannheim et al. (1978). Organisms isolated from the lung, middle ear and intestine of guinea pigs, previously reported as Avibacterium gallinarum, were subsequently reclassified with the SP group by Boot \& Bisgaard (1995). Finally, Stahel et al. (2009) reported on a group of organisms from various lesions in rabbits which demonstrated 99\% 16S rRNA sequence similarity to strain CCUG $28028^{\mathrm{T}}$ (=Michel A/ $76^{\mathrm{T}}$ ). However, reference was not given to the SP group. Frederiksen (1981), Aldová et al. (1992) and Lion et al. (1995) reported on human isolates and suggested that attention should be paid to these organisms also in medical laboratories.

The $\mathrm{G}+\mathrm{C}$ content of DNA of strain Michel $\mathrm{A} / 76^{\mathrm{T}}$ was estimated to be $52.5 \mathrm{~mol} \%\left(\mathrm{~T}_{\mathrm{m}}\right)$ (Mannheim et al., 1978). In addition, phenotypic characters excluded it from the family Pasteurellaceae according to Mannheim et al. (1978). DNA-DNA hybridization demonstrated that human isolates and isolates from guinea pigs should be classified in the same species, while the isolate of Stewart \& Letscher (1976) represented a different species of the same genus (Ursing, 1981). rRNA cistron similarities of taxa belonging to the family Pasteurellaceae, however, showed that strain Michel A $/ 76^{\mathrm{T}}$ grouped at the common root for rRNA branches of Pasteurella multocida, Actinobacillus lignieresii, Haemophilus influenzae and Aggregatibacter aphrophilus, while a human isolate (P602; Supplementary Table S1) was located at the common root for the abovementioned rRNA branches and Aggregatibacter actinomycetemcomitans (De Ley et al., 1990). Only minor differences were observed in polyamine patterns of members of the SP group and the organisms reported by Stewart \& Letscher (1976), and members of the SP and Stewart-Letscher (SL) groups also demonstrated polyamine relationships with other taxa of the family Pasteurellaceae (Busse et al., 1997). Using an ELISA, Boot et al. (1995) demonstrated that the SP group comprised a distinct serological group, different from taxons 5 and 6 of Bisgaard. Finally, a 16S rRNA gene sequence-based phylogeny showed that strain Michel A/76 ${ }^{\mathrm{T}}$ clustered with the rodent cluster (15) (Olsen et al., 2005).

In this study, we report the phenotypic and phylogenetic features of the SP group, and, based upon low genetic similarity to other genera of the family Pasteurellaceae and unique phenotype, we suggest the SP group be classified as Necropsobacter rosorum, gen. nov., sp. nov.

A total of 35 isolates from rodents (21), rabbits (eight), a dog and humans (five) (Supplementary Table S1) were investigated. Phenotypic characterization was carried out as reported previously (Bisgaard et al., 1991; Christensen et al., 2007).

Partial $r p o B$ sequences of all 35 isolates investigated (Supplementary Table S1) were determined according to Mollet et al. (1997), covering the region 509-680 (Escherichia coli positions) of the deduced protein sequence as reported previously (Angen et al., 2003; Korczak et al., 2004). Sequencing of the $16 \mathrm{~S}$ rRNA gene of 20 strains (Supplementary Table S1) was performed according to previous reports (Christensen et al., 2002; Kuhnert et al., 2002; Angen et al., 2003). BLAST search (Altschul et al., 1997) was performed in GenBank (Benson et al., 2010). Pairwise comparisons for similarity were performed by the program WATER included in EMBOSs (Rice et al. 2000). Multiple alignment was performed by using CLUSTAL $\mathrm{x}$ (Thompson et al. 1997). Phylogenetic trees were drawn using MEGA4 (Tamura et al., 2007). Maximum-likelihood analysis including bootstrap analysis was performed by using fastDNAml (Felsenstein 1995; Olsen et al. 1994) on a Linux compatible server. The analysis was run with a transition/transversion ratio of 1.3 .

Of the 35 isolates, 34 had highly related partial $r p o B$ gene sequences and formed a monophyletic group with $100 \%$ bootstrap support (Supplementary Fig. S1). From this group, 31 isolates including the type strain had almost identical $r p o B$ gene sequences whereas three strains (P602, K423-6 and ORG1719_03) showed a minimum of 97.4\% (ORG1719_03) rpoB gene sequence similarity to the type strain. The highest BLAST search similarity in GenBank was obtained with the group of 10 identical sequences already published (acc. nos EF579885-EF579894; Stahel et al., 2009) (Supplementary Table S1). All other sequences were distantly related, the closest value of $85 \% r p o B$ gene sequence similarity being to strain YU-ZK-12-LC (acc. no. GU167914) labelled as Gallibacterium anatis. Strain P625, representing the SL group, was only distantly related to the SP group described above $(86.4 \%$ similarity to the type strain) and other members of the family Pasteurellaceae. A comprehensive analysis of the use of $r p o B$ gene sequences for the phylogeny of the family Pasteurellaceae was reported by Korczak et al. (2004). In general, the rpoB gene provided higher resolution than the $16 \mathrm{~S}$ rRNA gene. Estimated similarities of partial $r p o B$ gene sequences within the family were more than $77 \%$, and generally more than $87 \%$ within a genus (Korczak \& Kuhnert, 2008). However, it should be remembered that the $85-90 \%$ similarity 
between genera of the family Pasteurellaceae at the partial $r p o B$ gene sequence level has also been observed for very different bacteria, such as members of the family Streptococcaceae, when only a short region is compared (Christensen \& Bisgaard, 2010).

Of the 20 isolates selected for $16 \mathrm{~S}$ rRNA gene sequence analysis, 19 formed a monophyletic group with $100 \%$ bootstrap support (Fig. 1), confirming the monophyly observed for the $r p o B$ gene (Supplementary Fig. S1). Sequence similarities of 98.5 (P1514-P602)-100\% were observed between isolates, including the 10 published sequences. For comparison, the type strains of the type species of existing genera of the family Pasteurellaceae were included, except for Haemophilus influenzae, for which the whole genomic sequence of strain Rd KW20 was used. The 16S rRNA gene sequence of the reference strain [Pasteurella] pneumotropica biovar Heyl was also included, as well as type strains of $[P$.$] pneumotropica and$ [Actinobacillus] muris. The group of 20 isolates investigated was only distantly related to other members of the family Pasteurellaceae, including the taxa $[P$.] pneumotropica and [Actinobacillus] muris, known to be associated with rodents. A BLAST search with 16S rRNA gene sequences showed highest similarity to isolate V6 from a rat (acc. no. AB279579), with $95.5 \%$ similarity to strain P981. The single strain, P625, representing the SL group, showed 94.9-95.5\% similarity to the SP group. Since similarities of $16 \mathrm{~S}$ rRNA gene sequences within the family Pasteurellaceae are greater than $89 \%$ and within a genus are generally greater than $93 \%$ (Korczak \& Kuhnert, 2008) and mostly below approximately $95 \%$ (Christensen et al., 2007), the SP group clearly represents a distinct genus from the $16 \mathrm{~S}$ rRNA perspective, for which the name Necropsobacter gen. nov. is proposed.

All strains of the SP group as well as strain P625 of the SL group showed a characteristic 16S rRNA nucleotide signature with three deletions in the region 203-206 (E. coli rrnB positions) and three in the region 213-214 compared with the type strain of $P$. multocida (acc. no. AY078999).

The 11 most divergent isolates based on 16S rRNA and $r p o B$ gene sequence analyses were further investigated by $r e c N$ gene sequencing. The $r e c N$ gene has proved useful in delineating genetic relatedness of strains as otherwise determined by DNA-DNA hybridization (Kuhnert \& Korczak, 2006). Primers recN_first-L (5'-ATGCTTANYCAWCTYACKATYAATMATTTTGC-3') and recN_first-R (5'-CCRCTAATYCCMACATCNACYTCATC- $3^{\prime}$ ) were used for amplification of $1.4 \mathrm{~kb}$ of the $1.7 \mathrm{~kb}$ gene at $50{ }^{\circ} \mathrm{C}$ annealing temperature. PCR products were sequenced with

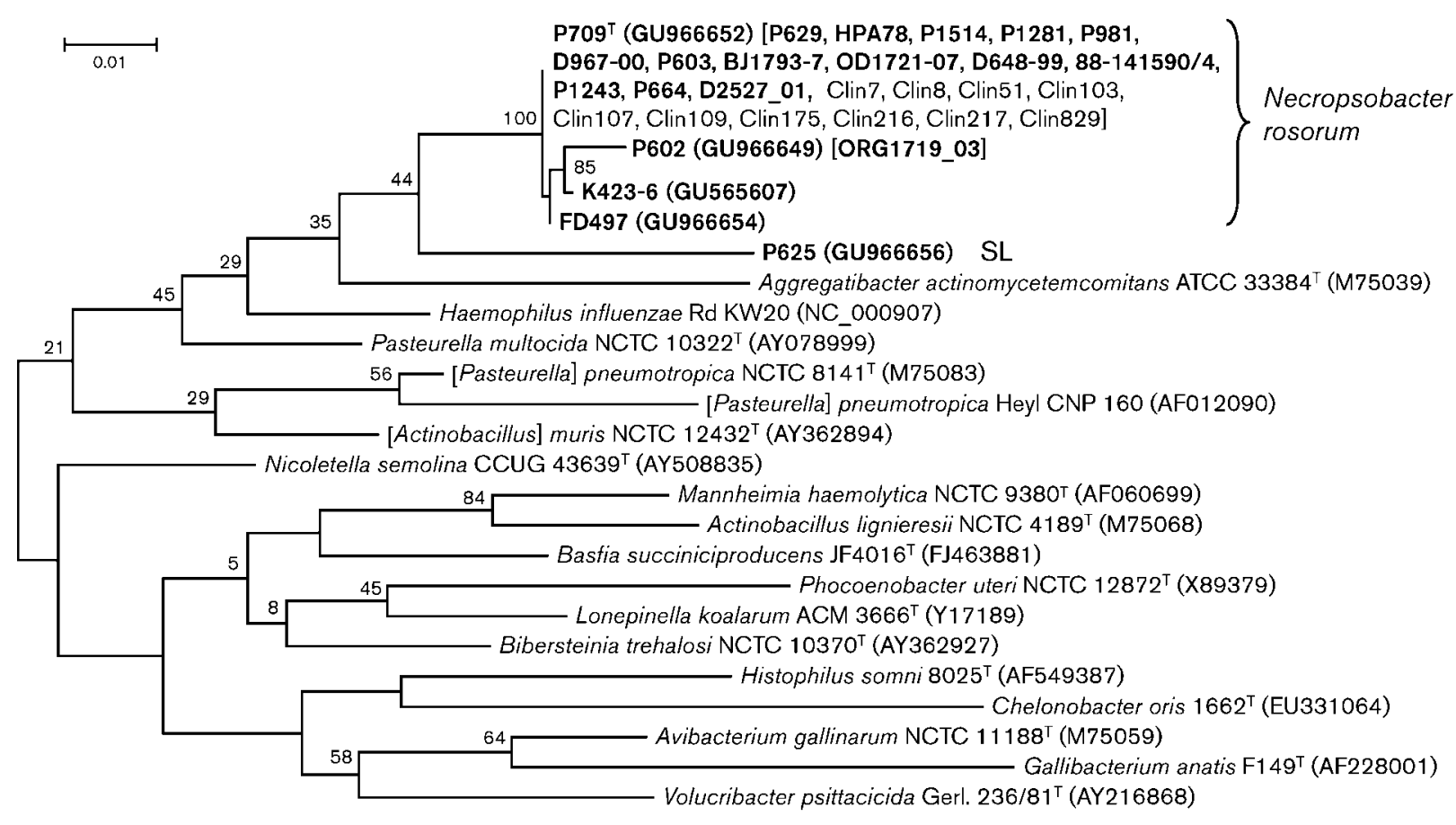

Fig. 1. Phylogenetic relationships between the isolates investigated and existing members of the family Pasteurellaceae based on maximum-likelihood analysis of near full-length 16S rRNA sequences. Support for monophyletic groups by bootstrapanalysis is indicated as numbers out of 100. DDBJ/EMBL/GenBank accession numbers are in parentheses. Strains in bold have been sequenced in the present investigation and the strains enclosed in square brackets share sequence with the preceding strain at the same branch with reference to Supplementary Table S1. Bar, evolutionary distance of 0.01 (represents sequence variation considering the models for nucleotide substitution and tree-shape used in the maximum-likelihood analysis). 
the same primers as well as the two internal primers recN-1 (5'-GTAAGTATTGATGCGCTGCTG-3') and recN-2 (5'CAGCAGCGCATCAATACTTAC-3') according to the protocol of Kuhnert \& Korczak (2006). The phylogenetic analysis showed that the 11 strains form a distinct branch separated from known taxa (Supplementary Fig. S2). The majority of SP group isolates showed identical recN sequences with the designated type strain Michel A/76 ${ }^{\mathrm{T}}$ while the other strains demonstrated more than $97.0 \%$ similarity. The single strain, P625, of the SL group differed from the strains of the SP group, only sharing $80 \%$ sequence similarity with them.

When genetic relatedness was calculated based on the formula of Zeigler (2003), all strains of the SP group had similarity values of at least 0.89 with strain Michel A/ $/ 76^{\mathrm{T}}$. When compared with the SL group strain, P625, this value was 0.56 (Table 1). Comparison of strain Michel A/76 ${ }^{\mathrm{T}}$ with strains representing 15 genera with validly published names indicated low similarity values. The highest value observed was 0.15 with Avibacterium gallinarum, consistent with the phylogenetic analysis (Supplementary Fig. S2). These values are clearly below the value of 0.4 normally indicating the threshold between genera. On the other hand, the close genetic and phylogenetic relationship observed between the SL and SP groups could argue for a common genus. However, more strains of the SL group need to be included to determine its taxonomic status. The $r e c N$ gene sequences can further be used as an approximation for the mol\% DNA $\mathrm{G}+\mathrm{C}$ content (Kuhnert \& Korczak, 2006): strains from the SP group showed $53.7-53.2 \mathrm{~mol} \% \mathrm{G}+\mathrm{C}$, the type strain, Michel A/76 ${ }^{\mathrm{T}}$, showed $53.2 \mathrm{~mol} \% \mathrm{G}+\mathrm{C}$ and the single SL

Table 1. Genetic similarity of strain CCUG $28028^{\top}$ to type species of genera of the family Pasteurellaceae based on recN sequences

\begin{tabular}{|c|c|}
\hline Strain & $\begin{array}{l}\text { Similarity to strain } \\
\text { CCUG } 28028^{\mathrm{T}}\end{array}$ \\
\hline SL group P625 & 0.56 \\
\hline Avibacterium gallinarum NCTC $11188^{\mathrm{T}}$ & 0.15 \\
\hline $\begin{array}{l}\text { Aggregatibacter actinomycetemcomitans } \\
\text { HK1651 }\end{array}$ & 0.14 \\
\hline Basfia succiniciproducens DSM $22022^{\mathrm{T}}$ & 0.14 \\
\hline $\begin{array}{l}\text { Pasteurella multocida CCUG } 17976^{\mathrm{T}} \\
\left(=\text { NCTC } 10322^{\mathrm{T}}\right)\end{array}$ & 0.09 \\
\hline Histophilus somni $8025^{\mathrm{T}}$ & 0.13 \\
\hline Lonepinella koalarum ATCC $700131^{\mathrm{T}}$ & 0.11 \\
\hline Haemophilus influenzae Rd KW20 & 0.10 \\
\hline Volucribacter psittacicida JEO101 & 0.01 \\
\hline Actinobacillus lignieresii NCTC $4189^{\mathrm{T}}$ & 0.02 \\
\hline Bibersteinia trehalosi NCTC $10370^{\mathrm{T}}$ & 0.00 \\
\hline Chelonobacter oris $1662^{\mathrm{T}}$ & 0.00 \\
\hline Gallibacterium anatis CCUG $15563^{\mathrm{T}}$ & 0.00 \\
\hline Mannheimia haemolytica NCTC $9380^{\mathrm{T}}$ & 0.00 \\
\hline Nicoletella semolina CCUG $43639^{\mathrm{T}}$ & 0.00 \\
\hline Phocoenobacter uteri NCTC $12872^{\mathrm{T}}$ & 0.00 \\
\hline
\end{tabular}

group strain, P625, only showed $48.3 \mathrm{~mol} \% \mathrm{G}+\mathrm{C}$. By the spectrophotometric method, the $\mathrm{G}+\mathrm{C}$ content of DNA $\left(\mathrm{T}_{\mathrm{m}}\right)$ for strain Michel A/76 ${ }^{\mathrm{T}}$ was estimated to be $52.5 \mathrm{~mol} \%$ (Mannheim et al., 1978) in correspondence within one per cent to the value estimated based on the $r e c N$ gene sequence. The DNA $\mathrm{G}+\mathrm{C}$ content of strain Michel $\mathrm{A} / 76^{\mathrm{T}}$ is the highest reported for genera of the family Pasteurellaceae, ranging from $36-47 \mathrm{~mol} \%$ for the genus Actinobacillus (Olsen \& Møller, 2005) to $44-47 \mathrm{~mol} \%$ for the genera Avibacterium and Chelonobacter (Blackall et al., 2005; Gregersen et al., 2009).

All strains included in the SP group tested positive for catalase and oxidase, and a fermentative reaction in Hugh and Leifson medium with $(+)$-D-glucose was observed. The strains stained Gram-negative and were coccoid or pleomorphic rods. Motility at 22 and $37{ }^{\circ} \mathrm{C}$ was not observed. Common positive phenotypic tests included porphyrin, methyl red (MR) at $37{ }^{\circ} \mathrm{C}$, nitrate reduction, phosphatase, and growth on MacConkey agar. Production of acid was observed from the carbohydrates listed in the genus and species descriptions. Positive reactions were observed for ONPG (o-nitrophenyl-D-galactopyranoside), $\alpha$-glucosidase $\quad$ (PNPG), $\alpha$-galactosidase, $\beta$-xylosidase (ONPX) and gas production from glucose. Negative reactions were observed for symbiotic growth, $\beta$-haemolysis, citrate (Simmons), urease, indole and pigment formation, and the characteristics listed in the genus and species descriptions.

Reactions observed were in accordance with those previously reported by Mannheim et al. (1978), Frederiksen (1981), Aldová et al. (1992) and Stahel et al. (2009). Stahel et al. (2009), however, reported on two atypical isolates. Differences in MR at $37{ }^{\circ} \mathrm{C}$ and production of acid from dulcitol, (+)-L-rhamnose and lactose separate the SP group from the organisms of Stewart \& Letscher (1976). Phenotypical results obtained for all strains investigated were in accordance with those reported for the family Pasteurellaceae (Olsen et al., 2005).

Only differences in haemolysis and production of acid from $(+)$-L-rhamnose and (-)-D-mannitol separate the SP group from the genus Gallibacterium, while differences in oxidase, MR at $37^{\circ} \mathrm{C}$, and $(+)$-L-arabinose separate the SP group from the genus Aggregatibacter (Table 2). However, contrary to the SP group, the genus Aggregatibacter demonstrates major variations in phenotypic characters, limiting the number of characters for separation. MR at $37^{\circ} \mathrm{C}$, and production of acid from $(+)$-L-rhamnose, $(+)$-xylose and dulcitol separate the SP group from the genus Avibacterium, while differences in acid production from dulcitol and trehalose and the reaction with $\alpha$-glucosidase (PNPG) separate the SP group from the genus Volucribacter. Differences in three or more characters also separate the SP group from the remaining genera of the family Pasteurellaceae (Table 2).

The ability to produce ubiquinones in addition to demethylmenaquinones characterizes major groups of the 
Table 2. Key characters for differentiation of the genera within the family Pasteurellaceae most closely related to the genus Necropsobacter gen. nov.

Genera: 1, Necropsobacter gen. nov., sp. nov. (this investigation); 2, Actinobacillus sensu stricto (Christensen \& Bisgaard, 2004); 3, Pasteurella sensu stricto (Christensen \& Bisgaard, 2006); 4, Haemophilus sensu stricto (includes H. influenzae, H. haemolyticus and H. aegyptius - results for H. parainfluenzae and H. pittmaniae are given in brackets) (Nørskov-Lauritsen et al., 2005); 5, Mannheimia (Angen et al., 1999); 6, Lonepinella (Osawa et al., 1995); 7, Phocoenobacter (Foster et al., 2000); 8, Gallibacterium (Bisgaard et al., 2009); 9, Volucribacter (Christensen et al., 2004); 10, Histophilus (Angen et al., 2003); 11, Avibacterium (Blackall et al., 2005; Bisgaard et al., 2007); 12, Nicoletella (Kuhnert et al., 2004); 13, Bibersteinia (Blackall et al., 2007); 14, Aggregatibacter (Nørskov-Lauritsen \& Kilian, 2006); 15, Chelonobacter (Gregersen et al., 2009); 16, Basfia (Kuhnert et al., 2010). Characters are scored as:,$+ 90 \%$ or more of strains positive within 1-2 days; $(+), 90 \%$ or more of strains positive within 3-14 days; -, fewer than $10 \%$ of strains positive within 14 days; $v, 11-89 \%$ of strains positive; ND, no data available.

\begin{tabular}{|c|c|c|c|c|c|c|c|c|c|c|c|c|c|c|c|c|}
\hline Characteristic & 1 & 2 & 3 & 4 & 5 & 6 & 7 & 8 & 9 & 10 & 11 & 12 & 13 & 14 & 15 & 16 \\
\hline Oxidase & + & $\mathrm{V}$ & + & + & $\mathrm{V}$ & - & + & $\mathrm{V}$ & V & + & + & + & $\mathrm{V}$ & - & + & + \\
\hline Methyl red test & + & - & - & $\mathrm{ND}$ & - & - & $\mathrm{ND}$ & + & + & $\mathrm{ND}$ & - & ND & - & - & $\mathrm{ND}$ & + \\
\hline Urease & - & + & $-{ }^{*}$ & $+[\mathrm{v}]$ & - & - & - & $\mathrm{V}$ & - & - & - & + & - & - & - & - \\
\hline Indole production & - & - & + & $\mathrm{v}$ & $\mathrm{V}$ & + & - & $\mathrm{V}$ & - & + & - & - & - & - & - & - \\
\hline$(+)$-L-Arabinose & + & $\mathrm{V}$ & - & - & $\mathrm{V}$ & $\mathrm{ND}$ & $\mathrm{ND}$ & $\mathrm{V}$ & $\mathrm{V}$ & $\mathrm{ND}$ & $\mathrm{V}$ & - & - & - & + & - \\
\hline$(+)$-D-Xylose & + & $\mathrm{V}$ & $\mathrm{V}$ & $\mathrm{v}$ & + & $\mathrm{ND}$ & - & $\mathrm{V}$ & $\mathrm{V}$ & - & - & - & - & $\mathrm{V}$ & + & + \\
\hline Dulcitol & + & - & $\mathrm{V}$ & - & - & $\mathrm{ND}$ & $\mathrm{ND}$ & $\mathrm{V}$ & - & $\mathrm{ND}$ & - & - & - & $\mathrm{ND}$ & + & - \\
\hline$(+)$-D-Galactose & + & $\mathrm{V}$ & + & $+/(+)$ & $\mathrm{V}$ & $\mathrm{ND}$ & $\mathrm{ND}$ & + & $+/(+)$ & - & $\mathrm{V}$ & - & - & $\mathrm{V}$ & ND & + \\
\hline$(+)$-L-Rhamnose & + & - & - & - & $\mathrm{V}$ & $\mathrm{ND}$ & $\mathrm{ND}$ & - & - & $\mathrm{ND}$ & - & ND & ND & $\mathrm{ND}$ & $\mathrm{ND}$ & - \\
\hline Maltose & + & + & - & + & $\mathrm{V}$ & $\mathrm{ND}$ & - & $\mathrm{V}$ & $\mathrm{V}$ & - & $\mathrm{V}$ & - & + & + & + & + \\
\hline
\end{tabular}

${ }^{\star}$ Discrepant results: Pasteurella dagmatis positive.

family Pasteurellaceae (Mannheim, 1981). Both ubiquinones and demethylmenaquinones were produced by strain Michel A/76 ${ }^{T}$ according to Mannheim et al. (1978), underlining the classification in the family Pasteurellaceae (Olsen et al., 2005). Polyamines were investigated by Busse et al. (1997), who showed that the major polyamine of representative strains (not the type strain) of the SP group is 1,3-diaminopropane, spermidine is present in moderate amounts and putrescine and spermine are detectable only in minor amounts. Fatty acids of strain CCUG $28028^{\mathrm{T}}$ were investigated by Culture Collection, University of Göteborg (CCUG) (Supplementary Table S2), who showed the major fatty acids to be $\mathrm{C}_{14: 0}, \mathrm{C}_{16: 0}, \mathrm{C}_{16: 1} \omega 7 c$ and summed feature $\mathrm{C}_{14: 0} 3-\mathrm{OH} /$ iso- $\mathrm{C}_{16: 1} \mathrm{I}$. This profile is typical for the type strains of the type species of the eight genera Haemophilus, Gallibacterium, Histophilus, Volucribacter, Nicoletella, Chelonobacter, Bibersteinia and Aggregatibacter whose data are available from CCUG (Supplementary Table S2). The data are also in agreement with the data of Mutters et al. (1993) for members of the family Pasteurellaceae known at that time. The exception was that they reported $\mathrm{C}_{16: 1} \omega 9 c$ to be a major fatty acid, whereas CCUG found $\mathrm{C}_{16: 1} \omega 7 c$ to constitute the majority of fatty acids in members of the family Pasteurellaceae. Assuming that data for CCUG $28028^{\mathrm{T}}$ can be compared to the other data at CCUG, small differences in proportions of $\mathrm{C}_{12: 0}$ existed between this strain and the type strains of the type species of the genera Histophilus and Chelonobacter. $\mathrm{C}_{18: 1} \omega 07 / 12 t / 9 t$ was not detected in CCUG $28028^{\mathrm{T}}$ but was found in minor amounts in the type strains of the type species of six other genera of the family Pasteurellaceae. Strain CCUG $28028^{\mathrm{T}}$ showed a fatty acid profile typical of the family Pasteurellaceae with limited or no possibility to distinguish the proposed genus from the existing genera of this family.

Results obtained from phenotypic and genotypic tests demonstrated good agreement. The monophyly of the new genus, Necropsobacter gen. nov., was clearly indicated by $16 \mathrm{~S}$ rRNA, rpoB and recN gene sequence analysis. Furthermore, the proposed genus, Necropsobacter gen. nov., fulfils the suggested minimal standards for description of members of the family Pasteurellaceae, including the number of strains investigated (Christensen et al., 2007). The authors desist from classification of the StewartLetscher group, since more strains are needed to demonstrate the possible divergence within this group. The high phenotypic and genetic homogeneity among the strains belonging to the SP group indicates the existence of a novel species within the genus Necropsobacter gen. nov., for which the name Necropsobacter rosorum sp. nov. is 
proposed. The genetic and phenotypic homogeneity of the species was demonstrated by more than 97.4 and $97.0 \%$ similarity in $r p o B$ and $r e c N$ gene sequences, respectively, and identical phenotypes for all isolates characterized.

\section{Description of Necropsobacter gen. nov.}

Necropsobacter (Ne.crop.so.bac'ter. Gr. n. nekros dead body, corpse; Gr. n. opsis appearance, view; N.L. masc. n. bacter a rod; N.L. masc. n. Necropsobacter a rod isolated from an autopsy).

Cells are non-motile at 22 and $37{ }^{\circ} \mathrm{C}$, Gram-stain-negative, coccoid or pleomorphic rods. Colonies on bovine blood agar are regular, circular and slightly raised with an entire margin. Haemolysis is not observed on bovine blood agar. Positive for catalase and oxidase, and show a fermentative reaction in Hugh and Leifson medium with (+)-D-glucose. Positive for the porphyrin test, nitrate reduction, $M R$ at $37^{\circ} \mathrm{C}$ and phosphatase. Produce acid from $(+)$-L-arabinose, (+)-L-rhamnose, (+)-D-xylose, dulcitol, (+)-D-galactose, $(+)$-D-mannose, maltose, trehalose and melibiose. A reaction is observed for $\alpha$-glucosidase (PNPG). Negative for symbiotic growth, urease, ornithine decarboxylase, indole and gas from $(+)$-D-glucose as well as production of acids from (-)-D-mannitol and the $\beta$-glucuronidase (PGUA) reaction. Both ubiquinones and demethylmenaquinones are produced by the type strain of the type species according to Mannheim et al. (1978). The G $+C$ content of DNA from the type strain of the type species is estimated to be $52.5 \mathrm{~mol} \%$ according to Mannheim et al. (1978). Major fatty acids are $\mathrm{C}_{14: 0}, \mathrm{C}_{16: 0}, \mathrm{C}_{16: 1} \omega 7 \mathrm{c}$ and summed feature $\mathrm{C}_{14: 0} 3-\mathrm{OH} /$ iso- $\mathrm{C}_{16: 1} \mathrm{I}$; minor fatty acids are listed in Supplementary Table S2. The type species is Necropsobacter rosorum.

\section{Description of Necropsobacter rosorum sp. nov.}

Necropsobacter rosorum (ro.so'rum. L. n. rosor -oris a rodent; L. gen. pl. n. rosorum of rodents).

Displays the following properties in addition to those given in the genus description. Colonies have a diameter of approximately $2.0 \mathrm{~mm}$ after $24 \mathrm{~h}$ of incubation at $37{ }^{\circ} \mathrm{C}$. The surface of the colonies is smooth, shiny and opaque with a greyish tinge. Colonies have an unguent-like consistency and do not adhere to the agar surface. Growth on MacConkey agar is positive. Production of acid is observed from glycerol (late), (+)-D-arabitol, (-)-D-ribose, $(-)$-D-fructose, $(-)$-L-fucose, $(+)$-D-glucose, lactose (late), sucrose, raffinose and dextrin. Positive reactions for ONPG, $\alpha$-galactosidase and $\beta$-xylosidase (ONPX). Negative reactions for citrate (Simmons), acid from mucic acid, malonate base, $\mathrm{H}_{2} \mathrm{~S} / \mathrm{TSI}, \mathrm{KCN}$ growth, Voges-Proskauer at $37{ }^{\circ} \mathrm{C}$, nitrate gas, arginine dehydrolase, lysine decarboxylase, phenylalanine deaminase, gelatinase, Tweens 20 and 80, and pigment formation. Acid is not produced from meso-erythritol, adonitol, xylitol, (-)-L-xylose, myo-inositol, (-)-D-sorbitol, (+)-D-fucose, (-)-L-sorbose, cellobiose, (+)-melezitose, (+)-D-glycogen, inulin, aesculin, amygdalin, arbutin, gentiobiose, salicin or (+)-turanose. Negative reactions are also observed for $\beta$-glucosidase (NPG), $\alpha$-fucosidase (ONPF) and $\alpha$-mannosidase. Strains reported have mainly been isolated from lesions in laboratory rodents, rabbits and human beings.

The type strain $\mathrm{P} 709^{\mathrm{T}}\left(=\right.$ Michel A/76 ${ }^{\mathrm{T}}=$ CCUG $28028^{\mathrm{T}}$ $=\mathrm{CIP} 110147^{\mathrm{T}}=\mathrm{CCM} 7802^{\mathrm{T}}$ ) was isolated from pneumonic lesions of a guinea pig.

\section{Acknowledgements}

Excellent technical assistance was contributed by technicians Pia Mortensen and Katrine Madsen. Drs Edward Moore and Ken Molin, Culture Collection, University of Göteborg, Sweden, are kindly thanked for performing the fatty acid analysis. We owe a great debt of gratitude to the scientists who have delivered their strains to this investigation. Finally, we would like to express our thanks to Professor Jean P. Euzéby, École Nationale Vétérinaire, Toulouse, France, for help with the Latin names.

\section{References}

Aldová, E., Frederiksen, W., Paucková, V., Absolonová, V., Vladik, P., Lávicková, M., Hausner, O.\& Vokoun, P. (1992). Aerogenic pasteurellas and Pasteurella-like organisms isolated in Czechoslovakia. Zentralbl Bakteriol 277, 139-143.

Altschul, S. F., Madden, T. L., Schäffer, A. A., Zhang, J., Zhang, Z., Miller, W. \& Lipman, D. J. (1997). Gapped BLAST and PSI-BLAST: a new generation of protein database search programs. Nucleic Acids Res 25, 3389-3402.

Angen, Ø., Ahrens, P., Kuhnert, P., Christensen, H. \& Mutters, R. (2003). Proposal of Histophilus somni gen. nov., sp. nov. for the three species incertae sedis 'Haemophilus somnus', 'Haemophilus agni' and 'Histophilus ovis'. Int J Syst Evol Microbiol 53, 1449-1456.

Angen, Ø., Mutters, R., Caugant, D. A., Olsen, J. E. \& Bisgaard, M. (1999). Taxonomic relationships of the [Pasteurella] haemolytica complex as evaluated by DNA-DNA hybridizations and 16S rRNA sequencing with proposal of Mannheimia haemolytica gen. nov., comb. nov., Mannheimia granulomatis comb. nov., Mannheimia glucosida sp. nov., Mannheimia ruminalis sp. nov. and Mannheimia varigena sp. nov. Int J Syst Bacteriol 49, 67-86.

Benson, D. A., Karsch-Mizrachi, I., Lipman, D. J., Ostell, J. \& Sayers, E. W. (2010). GenBank. Nucleic Acids Res 38 (Database issue), D46D51.

Bisgaard, M., Houghton, S. B., Mutters, R. \& Stenzel, A. (1991). Reclassification of German, British and Dutch isolates of so-called Pasteurella multocida obtained from pneumonic calf lungs. Vet Microbiol 26, 115-124.

Bisgaard, M., Christensen, J. P., Bojesen, A. M. \& Christensen, H. (2007). Avibacterium endocarditidis sp. nov., isolated from valvular endocarditis in chickens. Int J Syst Evol Microbiol 57, 1729-1734.

Bisgaard, M., Korczak, B. M., Busse, H.-J., Kuhnert, P., Bojesen, A. M. \& Christensen, H. (2009). Classification of the taxon 2 and taxon 3 complex of Bisgaard within Gallibacterium and description of Gallibacterium melopsittaci sp. nov., Gallibacterium trehalosifermentans sp. nov. and Gallibacterium salpingitidis sp. nov. Int J Syst Evol Microbiol 59, 735-744.

Blackall, P. J., Christensen, H., Beckenham, T., Blackall, L. L. \& Bisgaard, M. (2005). Reclassification of Pasteurella gallinarum, [Haemophilus] paragallinarum, Pasteurella avium and Pasteurella volantium as Avibacterium gallinarum gen. nov., comb. nov., 
Avibacterium paragallinarum comb. nov., Avibacterium avium comb. nov. and Avibacterium volantium comb. nov. Int J Syst Evol Microbiol 55, 353-362.

Blackall, P. J., Bojesen, A. M., Christensen, H. \& Bisgaard, M. (2007). Reclassification of [Pasteurella] trehalosi as Bibersteinia trehalosi gen. nov., comb. nov. Int J Syst Evol Microbiol 57, 666-674.

Boot, R. \& Bisgaard, M. (1995). Reclassification of 30 Pasteurellaceae strains isolated from rodents. Lab Anim 29, 314-319.

Boot, R., Thuis, H., Bakker, R. H. G. \& Veenema, J. L. (1995). An enzyme-linked immunosorbent assay (ELISA) for monitoring antibodies to SP group Pasteurellaceae in guineapigs. Lab Anim 29, 59-65.

Busse, H.-J., Bunka, S., Hensel, A. \& Lubitz, W. (1997). Discrimination of members of the family Pasteurellaceae based on polyamine patterns. Int J Syst Bacteriol 47, 698-708.

Christensen, H. \& Bisgaard, M. (2004). Revised definition of Actinobacillus sensu stricto isolated from animals. A review with special emphasis on diagnosis. Vet Microbiol 99, 13-30.

Christensen, H. \& Bisgaard, M. (2006). The genus Pasteurella. In The Prokaryotes, 3rd edn, vol. 6, pp. 1062-1090. Edited by M. Dworkin, S. Falkow, E. Rosenberg, K. H. Schleifer \& E. Stackebrandt. New York: Springer.

Christensen, H. \& Bisgaard, M. (2008). Taxonomy and biodiversity of members of Pasteurellaceae. In Pasteurellaceae: Biology, Genomics and Molecular Aspects, pp. 1-26. Edited by P. Kuhnert \& H. Christensen. Wymondham, UK: Caister Academic Press.

Christensen, H. \& Bisgaard, M. (2010). Molecular classification and its impact on diagnostics and understanding the phylogeny and epidemiology of selected members of Pasteurellaceae of veterinary importance. Berl Munch Tierarztl Wochenschr 123, 20-30.

Christensen, H., Bisgaard, M., Angen, Ø. \& Olsen, J. E. (2002). Final classification of Bisgaard taxon 9 as Actinobacillus arthritidis sp. nov. and recognition of a novel genomospecies for equine strains of Actinobacillus lignieresii. Int J Syst Evol Microbiol 52, 1239-1246.

Christensen, H., Bisgaard, M., Aalbæk, B. \& Olsen, J. E. (2004). Reclassification of Bisgaard taxon 33, with proposal of Volucribacter psittacicida gen. nov., sp. nov. and Volucribacter amazonae sp. nov. as new members of the Pasteurellaceae. Int J Syst Evol Microbiol 54, 813-818.

Christensen, H., Kuhnert, P., Busse, H.-J., Frederiksen, W. C. \& Bisgaard, M. (2007). Proposed minimal standards for the description of genera, species and subspecies of the Pasteurellaceae. Int J Syst Evol Microbiol 57, 166-178.

De Ley, J., Mannheim, W., Mutters, R., Piechulla, K., Tytgat, R., Segers, P., Bisgaard, M., Frederiksen, W., Hinz, K.-H. \& Vanhoucke, M. (1990). Inter- and intrafamilial similarities of rRNA cistrons of the Pasteurellaceae. Int J Syst Bacteriol 40, 126-137.

Felsenstein, J. (1995). PHYLIP (phylogeny inference package) version 3.5c. Distributed by the author. Department of Genome Sciences, University of Washington, Seattle, USA.

Foster, G., Ross, H. M., Malnick, H., Willems, A., Hutson, R. A., Reid, R. J. \& Collins, M. D. (2000). Phocoenobacter uteri gen. nov., sp. nov., a new member of the family Pasteurellaceae Pohl (1979) 1981 isolated from a harbour porpoise (Phocoena phocoena). Int J Syst Evol Microbiol 50, 135-139.

Frederiksen, W. (1981). Gas producing species within Pasteurella and Actinobacillus. In Haemophilus, Pasteurella and Actinobacillus, pp. 185-196. Edited by M. Kilian, W. Frederiksen \& E. L. Biberstein. London: Academic Press.

Gregersen, R. H., Neubauer, C., Christensen, H., Bojesen, A. M., Hess, M. \& Bisgaard, M. (2009). Comparative studies on [Pasteurella] testudinis and [P.] testudinis-like bacteria and proposal of Chelonobacter oris gen. nov., sp. nov. as a new member of the Pasteurellaceae. Int J Syst Evol Microbiol 59, 1583-1588.

Jukes, T. H. \& Cantor, C. R. (1969). Evolution of protein molecules. In Mammalian Protein Metabolism, vol. 3, pp. 21-132. Edited by H. N. Munro. New York: Academic Press.

Korczak, B. M. \& Kuhnert, P. (2008). Phylogeny of Pasteurellaceae. In Pasteurellaceae: Biology, Genomics and Molecular Aspects, pp. 27-52. Edited by P. Kuhnert \& H. Christensen. Wymondham, UK: Caister Academic Press.

Korczak, B., Christensen, H., Emler, S., Frey, J. \& Kuhnert, P. (2004). Phylogeny of the family Pasteurellaceae based on rpoB sequences. Int $J$ Syst Evol Microbiol 54, 1393-1399.

Kuhnert, P. \& Korczak, B. M. (2006). Prediction of wholegenome DNA-DNA similarity, determination of $\mathrm{G}+\mathrm{C}$ content and phylogenetic analysis within the family Pasteurellaceae by multilocus sequence analysis (MLSA). Microbiology 152, 2537-2548.

Kuhnert, P., Frey, J., Lang, N. P. \& Mayfield, L. (2002). Phylogenetic analysis of Prevotella nigrescens, Prevotella intermedia and Porphyromonas gingivalis clinical strains reveals a clear species clustering. Int J Syst Evol Microbiol 52, 1391-1395.

Kuhnert, P., Korczak, B., Falsen, E., Straub, R., Hoops, A., Boerlin, P., Frey, J. \& Mutters, R. (2004). Nicoletella semolina gen. nov., sp. nov., a new member of Pasteurellaceae isolated from horses with airway disease. J Clin Microbiol 42, 5542-5548.

Kuhnert, P., Scholten, E., Haefner, S., Mayor, D. \& Frey, J. (2010). Basfia succiniciproducens gen. nov., sp. nov., a new member of the family Pasteurellaceae isolated from bovine rumen. Int J Syst Evol Microbiol 60, 44-50.

Lion, C., Conroy, M. C., Dupuy, M. L. \& Escande, F. (1995). Pasteurella "SP" group infection after a guinea pig bite. Lancet 346, 901-902.

Mannheim, W. (1981). Taxonomic implications of DNA relatedness and quinone patterns in Haemophilus, Pasteurella and Actinobacillus. In Haemophilus, Pasteurella and Actinobacillus, pp. 265-280. Edited by M. Kilian, W. Frederiksen \& E. L. Biberstein. London: Academic Press.

Mannheim, W., Pohl, S. \& Stenzel, W. (1978). [Unclassified Pasteurella-like organisms isolated from guinea pigs]. Zentralbl Bakteriol (Orig A) 241, 329-336 (in German).

Mollet, C., Drancourt, M. \& Raoult, D. (1997). rpoB sequence analysis as a novel basis for bacterial identification. Mol Microbiol 26, 1005-1011.

Mutters, R., Mouahid, M., Engelhard, E. \& Mannheim, W. (1993). Characterization of the family Pasteurellaceae on the basis of cellular lipids and carbohydrates. Zentralbl Bakteriol 279, 104-113.

Nørskov-Lauritsen, N. \& Kilian, M. (2006). Reclassification of Actinobacillus actinomycetemcomitans, Haemophilus aphrophilus, Haemophilus paraphrophilus and Haemophilus segnis as Aggregatibacter actinomycetemcomitans gen. nov., comb. nov., Aggregatibacter aphrophilus comb. nov. and Aggregatibacter segnis comb. nov., and emended description of Aggregatibacter aphrophilus to include V factordependent and V factor-independent isolates. Int J Syst Evol Microbiol 56, 2135-2146.

Nørskov-Lauritsen, N., Bruun, B. \& Kilian, M. (2005). Multilocus sequence phylogenetic study of the genus Haemophilus with description of Haemophilus pittmaniae sp. nov. Int J Syst Evol Microbiol 55, 449-456.

Olsen, I. \& Møller, K. (2005). Genus Actinobacillus Brumpt 1910, $849^{\mathrm{AL}}$. In Bergey's Manual of Systematic Bacteriology, 2nd edn, vol. 2, pp. 866-883. Edited by D. J. Brenner, N. R. Krieg, J. T. Staley \& G. M. Garrity. New York: Springer. 
Olsen, G. J., Matsuda, H., Hagstrom, R. \& Overbeek, R. (1994). fastDNAmL: a tool for construction of phylogenetic trees of DNA sequences using maximum likelihood. Comput Appl Biosci 10, 41-48.

Olsen, I., Dewhirst, F. E., Paster, B. J. \& Busse, H.-J. (2005). Family Pasteurellaceae. In Bergey's Manual of Systematic Bacteriology, 2nd edn, vol. 2, pp. 851-856. Edited by D. J. Brenner, N. R. Krieg, J. T. Staley \& G. M. Garrity. New York: Springer.

Osawa, R., Rainey, F. A., Fujisawa, T., Lang, E., Busse, H.-J., Walsh, T. \& Stackebrandt, E. (1995). Lonepinella koalarum gen. nov., sp. nov., a new tannin-protein complex degrading bacterium. Syst Appl Microbiol 18, 368-373.

Rice, P., Longden, I. \& Bleasby, A. (2000). EMBoss: the European molecular biology open software suite. Trends Genet 16, 276-277.

Stahel, A. B. J., Hoop, R. K., Kuhnert, P. \& Korczak, B. M. (2009). Phenotypic and genetic characterization of Pasteurella multocida and related isolates from rabbits in Switzerland. J Vet Diagn Invest 21, 793-802.
Stewart, D. D. \& Letscher, R. M. (1976). Isolation of an atypical Pasteurella-like organism from guinea pig abscesses. Lab Anim Sci 26, 482-485.

Tamura, K., Dudley, J., Nei, M. \& Kumar, S. (2007). MEGA4: molecular evolutionary genetics analysis (MEGA) software version 4.0. Mol Biol Evol 24, 1596-1599.

Thompson, J. D., Gibson, T. J., Plewniak, F., Jeanmougin, F. \& Higgins, D. G. (1997). The CLUSTAL_X windows interface: flexible strategies for multiple sequence alignment aided by quality analysis tools. Nucleic Acids Res 25, 4876-4882.

Ursing, J. (1981). Deoxyribonucleic acid hybridization studies of gas producing Pasteurellaceae. In Haemophilus, Pasteurella and Actinobacillus, pp. 255-263. Edited by M. Kilian, W. Frederiksen \& E. L. Biberstein. London: Academic Press.

Zeigler, D. R. (2003). Gene sequences useful for predicting relatedness of whole genomes in bacteria. Int J Syst Evol Microbiol 53, 1893-1900. 